\title{
Notions and Subnotions in Information Structure*
}

\author{
Carlos Gussenhoven \\ Radboud University Nijmegen
}

\begin{abstract}
Three dimensions can be distinguished in a cross-linguistic account of information structure. First, there is the definition of the focus constituent, the part of the linguistic expression which is subject to some focus meaning. Second and third, there are the focus meanings and the array of structural devices that encode them. In a given language, the expression of focus is facilitated as well as constrained by the grammar within which the focus devices operate. The prevalence of focus ambiguity, the structural inability to make focus distinctions, will thus vary across languages, and within a language, across focus meanings.
\end{abstract}

Keywords: corrective focus, contrastive focus, informational focus, focus ambiguity, focus type, focus meaning

\section{Introduction}

The challenge in descriptions of information structure lies in determining the relation between information structural meanings and the surface structures of linguistic expressions. Three dimensions can be recognized. First, there is the identification of the focus constituent, the constituent which is subject to some focus meaning. Most obviously, this dimension concerns differences between 'broad' and 'narrow' focus (Ladd 1980). Second, there are the focus meanings themselves, sometimes referred to as 'focus types' (Dik et al. 1980; Gussenhoven 2006). Given that different focus meanings are expressed in

I thank Gorka Elordieta and Mariko Sugahara for helpful comments on an earlier version of this text.

Interdisciplinary Studies on Information Structure 6 (2007): 185-203

Féry, C., G. Fanselow, and M. Krifka (eds.):

The Notions of Information Structure

(C)2007 Carlos Gussenhoven 
different ways, the third and last dimension is the expression of focus, the structural means by which focus meanings are encoded.

This contribution is concerned with pointing out that the structural devices employed for the expression of focus meanings are integrated in the grammar of the language. There are two potential disturbances in the relation between the semantic focus constituent and the structure used to encode it. The first is that the structural device may be subject to constraints that are unrelated to information structure, so that the expression of information structure may be frustrated because of focus ambiguity, i.e., the existence of identical phonological structures for expressions with different focus constituents. English exemplifies the situation by using deaccenting for multiple purposes, only one of which is to indicate that the deaccented words occur outside the focus constituent. Among the other functions is a rule deaccenting the second constituent of compounds. As a result, the phonological structure in (1) is ambiguous between the expressions (1a) and (1b). The second circumstance frustrating a one-to-one mapping between the focus constituent and the device used to express it is that a structural device has an intrinsic minimal size. For instance, the pitch accent indicated by capitalization in (1) is phonologically associated with a stressed syllable, with the result that no focus constituent below the level of the syllable can be phonologically encoded. This is illustrated by the expression in (1c), in which the focus constituent is the initial consonant, in a metalinguistic reference.

(1) The WHITE house

$\% \mathrm{~L} \quad \mathrm{H} * \mathrm{~L} \quad \mathrm{~L} \%$

a. The $\left[(\text { white house })_{\mathrm{N}}\right]_{\mathrm{FOC}}$

('What's the name of the presidential palace in the USA?') 


\section{b. (The [white $]_{\mathrm{FOC}}$ house $)_{\mathrm{NP}}$ ('Which house do you mean?') \\ c. (The $[w h]_{\mathrm{FOC}}$ ite house $)_{\mathrm{NP}}$ ('You mentioned the lighthouse')}

While the structure used for $(1 \mathrm{a}, \mathrm{b}, \mathrm{c})$ is the same, there may be more or less systematic phonetic differences between one meaning and the next. For instance, van Heuven (1994) found that Dutch cases equivalent to (1c) are pronounced with a somewhat later pitch fall than responses to some such question as Did you say the 'wait house'?, in which the vowel will be the focus constituent. Although they have not been systematically reported, there may be phonetic differences too between 'corrective' occurrences of (1) ('Did you mean the Senate?') and 'informational' uses as in (1a) (see also below). These semantically motivated differences in phonetic implementation, which may be language-specific, require more research, and are not the topic of this contribution.

\section{Size of the Focus Constituent}

'Broad' and 'narrow' are relative terms for the size of the focus constituent (Ladd 1980). In (2b), the focus constituent is smaller than in (2a), while it shifts to the temporal element in the verb in $(2 \mathrm{c})$.

(2) a. (A: What else can you tell us about Helen?)

B: She [used to drive a Renault CLIO $]_{\mathrm{FOC}}$

b. (A: What kind of Renault did she drive?)

B: She used to drive a Renault $[\mathrm{CLIO}]_{\mathrm{FOC}}$

c. (A: Does she drive a Renault CLIO?)

B: She [USED TO $]_{\text {FOC }}$ drive a Renault Clio 
Example (2c) suggests that the nature of the focus constituent would appear to be semantic. It is not necessarily the case that there are words that directly represent the semantic focus. Instead of used to drive, the speaker might have preferred the past tense form drove. It would be accented, even though the verb itself is outside the focus constituent, which comprises only the tense feature [PAST]. Bolinger (1983) discussed cases like these as 'Affirmation accent'. Instead of [PAST] the polarity may be in focus, as in No, she DIDn't drive a Renault Clio.

\section{Expressing Meanings of Focus}

Phonological prominence typically accompanies the focus constituent. However, this prominence may be achieved in structurally different ways in different languages. Also, in some languages it is not there. In such cases, the expression of focus is exclusively reflected in the morpho-syntax and does not lead to phonological prominence. Broadly, the structural devices used to express information structure can be listed as follows.

1. Syntax
a) position in syntactic structure
b) focus particle

2. Morphology
a) affixation

3. Phonology
a) presence of pitch accent
b) type of pitch accent
c) prosodic phrasing 
The identification of a focus meaning should be based on the existence of two phonological surface structures that encode identical focus constituents. For instance, in both $(3 a, b)$ the proposition 'we be in France' represents given information and in both cases the new information is the negation of that proposition. The difference between them is that in (3a) the speaker prevents the proposition from being added to the mutual knowledge base ('counterassertive focus' in Gussenhoven (1983), Dik et al. (1980), also 'corrective focus' in Elordieta and Hualde (2003), Elordieta (2007a)), while the speaker of (3b) acts so as the remove the proposition from the mutual knowledge base ('debugging the background', cf. Gussenhoven (1983)). This difference in the structural expression between corrective and 'counterpresuppositional focus' exists in West Germanic languages if the focus constituent is the polarity of the proposition.
(3) a. (A: We're in France)
B: We're $[\mathrm{NOT}]_{\mathrm{FOC}}$ in France
b. (A: We need to speak French now, remember!)
B: We're $[\text { not }]_{\mathrm{FOC}}$ IN France

In the remainder of this section, meanings and ways of expressing them are discussed in tandem, as they are inevitably intertwined. The discussion is not claimed to be exhaustive.

\subsection{Morphosyntax}

\subsubsection{Position in syntactic structure}

According to Kügler and Skopeteas (2006), Yucatec Maya, a VOS language, places the focus constituent in preverbal position, as in (4a), which contrasts with the neutral (4b). 


\section{(4) a. òon t-u hàant-ah Pedro avocado PVF-A.3 eat+TRR-COMPL+B3+SG Pedro 'It was an avocado that Pedro ate'}

b. $\quad$ t-u hàant-ahòon Pedro 'Pedro ate an avocado'

Untypically, there are no prosodic effects of the difference in focus structure. The prosodic boundary after òon in (4a) is no different from that between the words in (4b). Neither is information structure marked by other prosodic elements. In a reading task with four speakers, sentences like $(5 \mathrm{a}, \mathrm{b})$ consistently received identical pronunciations (Gussenhoven and Teeuw 2007).
a. Má kin mèentik [ek $]_{\mathrm{FOC}}$, kin mèentik [us $]_{\mathrm{FOC}}$ 'I'm not making a wasp, I'm making a gnat'
b. Má kin $[\text { kachik }]_{\mathrm{FOC}}$ us, kin [mèentik $]_{\mathrm{FOC}}$ us 'I'm not destroying a gnat, I'm making a gnat'

More typically, information structure is encoded in more than one type of structure, either independently or by implication. When languages designate a position in structure as a focus position, the phonological phrasing may be implicated, or there may be independent phrasing requirements. Lekeitio Basque (LB) requires the focus constituent to be in the final XP, disregarding the sentencefinal verb. That is, (6) is ungrammatical if 'to the teacher' is the focus constituent (cf. A1), but not if 'of the friends' (cf. A2), 'the books' or 'the books of the friends' are (cf. A3). 
(6) A1: To whom did you give the book?

[the teacher $]_{\mathrm{FOC}}$

A2: Whose book did you give to the teacher? [the friends' $]_{\mathrm{FOC}}$

A3: What possession of the friends did you give to the teacher?

A4: What did you give to the teacher?

[the books $]_{\mathrm{FOC}}$

B: maixuári lagúnen liburúak emon dotzaras

teacher+DAT friends+DAT books give AUX

'I gave the friends' books to the teacher'

The replies to A2, A3 and A4 have the same phonological representation. However, this is true only under 'information focus' (Kiss 1998), as in the answer to a question. With corrective focus for liburúak, the sentence would be distinct from the versions in which either lagúnen liburúak or lagúnen are in focus, because a corrective focus constituent begins with the boundary of an intermediate phrase (henceforth ip), which would not otherwise be there before liburúak. Within an ip, accents are downstepped, and so a corrective focus constituent in Basque avoids being downstepped by virtue of its initial position in the downstep domain. Phrasing-for-focus thus has the effect that the focus constituent is made prominent through the suppression of downstep.

Interestingly, the grammar of LB constrains the expression of focus by disallowing prosodic boundaries after unaccented words. Since accentuation is a lexical property, the choice of one word over the next can determine whether the focus constituent can be expressed. Replacing accented lagúnen with unaccented nebien, as in (7), will make it impossible for many speakers to prosodically single out liburúak, because it will form a single accentual phrase (henceforth $\alpha$ ) with nebien. Obviously, no ip-boundary can be placed inside the lower-ranked a. Similarly, no speaker of LB could express narrow corrective focus for nebien, as there would be no way to separate the word off in an $\alpha$ of its own. Any range expansion would apply to the entire $\alpha$ (Elordieta 2007b). 
(7) a. $\left\{(\text { maixuári })_{\alpha}\right\}_{\text {ip }}\left\{\left(\text { nebien } \quad[\text { liburúak }]_{\text {FOC }}\right)_{\alpha}\right\}_{\text {ip }}$ emon dotzaras teacher+DAT brother+GEN books give AUX 'I gave the brother's books to the teacher'

b. $\left\{(\text { maixuári })_{\alpha}\right\}_{\text {ip }}\left\{\left([\text { nebien }]_{\text {FOC }} \text { liburúak }\right)_{\alpha}\right\}_{\text {ip }}$ emon dotzaras

Wolof, an SVO language, uses left dislocation for given constituents. Such topicalization will not alter the surface word order if the topicalized constituent would otherwise be sentence-initial, but it will cause an Intonational Phrase ( 1 ) boundary after it. The focus constituent appears immediately before the verb, with which it must occur in the same 1 . Thus, in (8), the focus constituent mburu $m i$ precedes la lekk and shares an 1 with it. Without topicalization, the clause would be a single 1, with no l-boundary after Peer (Robert 2000; Rialland and Robert 2001). Perhaps a little paradoxically, then, a prosodic break after a sentenceinitial constituent marks it as being outside the focus constituent.

$$
\begin{aligned}
& \{\text { Peer }\}_{\iota}\{\text { mburu mi la lekk }\}_{l} \\
& \text { Peter 3SG+OBJFOC bread the eat } \\
& \text { 'Peter ate the BREAD' }
\end{aligned}
$$

\subsubsection{Particles}

Particles may be used to express different focus meanings. Japanese $w a$, placed after the subject in this SOV language, marks the subject as given or reactivated information. It competes with $g a$, which marks the subject as new information. That is, (9a) implies that the subject is included in the focus constituent, but is otherwise ambiguous as to whether the focus constituent is larger than the subject or whether there is a further focus constituent. Conversely, (9b) conveys that the focus constituent is not the subject, and therefore must be somewhere in the remainder of the sentence (cf. Susumu 1973). 
(9) a. A1: Who gave a book to whom? [Kaoru $]_{\mathrm{FOC}},[\text { Keiko }]_{\mathrm{FOC}}$

A2: What was going on? [Kaoru Keiko ni hon o ageta $]_{F O C}$

B: Kaoru ga Keiko ni hon o ageta

Kaoru FOC Keiko to book OBJ gave

'Kaoru gave a book to Keiko'

b. A1: Who did Kaoru give the book to? [Keiko $]_{\mathrm{FOC}}$

A2: What did Kaoru give Keiko? [hon o] $]_{\mathrm{FOC}}$

A3: What's with Kaoru? [Keiko ni hon o ageta $]_{\mathrm{FOC}}$

B: Kaoru wa Keiko ni hon o ageta

As may be expected, the prosodic structures of the sentences with different focus structures may differ. As in the case of the corrective focus in LB, the focus constituent in Japanese, whether informational or corrective, quite generally begins an ip (Pierrehumbert and Beckman 1988). The treatment of the end of the focus constituent is less straightforward, but is likely to be treated so as to favour pitch range expansion for the focus constituent (Sugahara 2002).

Sundanese has three particles expressing different focus meanings, to be attached to the syntactic phrase, indicated by parentheses in (10), (11) and (12). Mah signals information focus, tae topic (or 'reactivating focus'), while teh signals given information. Example (10) shows how teh can be used to mark old information in a question, and how mah is used to mark the requested information. Interestingly, as shown by (11), the constituent carrying old information ('interesting') may occur inside the XP to which the particle is attached. That is, there must be focus ambiguity between (11) and an equivalent case with Komo kae kataji as the focus constituent. In (12), finally, the speaker uses tae to mark 'water' as recoverable information which is re-activated ('As for the water...') (Müller-Gotama 1996). 
(10) A: (Anu indit ka pasar)-teh [saha $]_{\mathrm{FOC}}$ REL go to market-GIVEN who

'WHO then is the one going to the market?'

$\mathrm{B}: \mathrm{Nu}$ indit ka pasar $[\text { (Dadas) }]_{\mathrm{FOC}}-\mathrm{mah}$ REL go to market Dadas-FOC

'DADAS is going to the market'

(11) A: (Eusina buku eta)-the naha kataji? contents+POSS book that-GIVEN Q interesting 'Are the contents of that book INTERESTING?'

B: ([Komo bae $]_{F O C}$ kataji)-mah above all interesting-FOC 'VERY interesting'

(12) $[(\text { Cai })]_{\text {TOP-tae diteundeun kana meja }}$ water-TOP PASS+put to table 'The water was put on the table'

Bulgarian and Russian have a question particle $l i$, which occurs in second position in the clause. It effectively marks narrow focus if attached to a syntactic phrase, but broad focus if attached to the verb. Thus, Russian (13) is a narrow focus sentence, but (14) has broad focus (Rudin, King, and Izvorski 1998).

(13) $[(\text { Knigu })]_{\text {FOC }}$ li Anna pročitala?

book Q Anna read

'Did Anna read a BOOK?'

(14) $\quad[\text { (Pročitala) li Anna knigu }]_{\mathrm{FOC}}$

'Did Anna read a book?'

\subsection{Morphology}

Wolof has a set of verbal affixes expressing information structure by the side of aspectual and temporal information. They take different forms depending on person (Robert 1991; Rialland and Robert 2001). For instance, in a sentence 
with broad focus and 'presentative' aspect, a verb form indicating temporal and locative coincidence with the speech act takes the paradigm in the first column of (15), which contains the stem for 'eat'. There are some nine further paradigms, among which are the three given in columns 2, 3 and 4, the choice among these latter three depending on the focus constituent. Thus, (16a) is a neutral sentence, (16b) has the verb in focus, and in (16c) '(s)he' is in focus. Unlike the forms in columns 1, 2 and 3, which can be free-standing expressions, those in column 4 require a preceding object.

$\begin{array}{lllll} & \text { Presentative } & \text { Verb focus } & \text { Subj focus } & \text { Obj focus } \\ \text { 1 SG } & \text { maa ngi lekk } & \text { dama lekk } & \text { maa lekk } & \text { laa lekk } \\ 2 & \text { yaangi lekk } & \text { dangalekk } & \text { yaa lekk } & \text { nga lekk } \\ 3 & \text { mu ngi lekk } & \text { da(fa)lekk } & \text { moo lekk } & \text { la lekk } \\ 1 \text { SG } & \text { nu ngi lekk } & \text { danu lekk } & \text { noo lekk } & \text { lanu lekk } \\ 2 & \text { yeena ngi lekk } & \text { dangeen lekk } & \text { yeena lekk } & \text { ngeen lekk } \\ 3 & \text { ñu ngi lekk } & \text { dañu lekk } & \text { ñoo lekk } & \text { lañu lekk }\end{array}$

(16)a.

Peer mu ngi lekk
Peter 3SCSG+PRESENTATIVE eat
'Peter is eating'

c. Moo lekk mburu mi 3SG+SUBJFOC eat bread the '(S)HE ate the bread'
b. Peer dafa Peter 3SG+VERBFOC eat 'Peter DID EAT'
d. Loolu la lekk that 3SG+OBJFOC eat '(S)he ate THAT'

Irish has a set of suffixes that attach to an NP containing a personal pronoun (Cotter 1996). The suffix may signal focus for a pronominal NP, as in (17b), where 3SG sean attaches to sei, but also for the possessive in a lexically explicit Noun Phrase, as in (17a), where 1SG se attaches to athair, but expresses focus for $m$. A lexically explicit NP can be focused with the help of the morpheme féin 'self'. In addition, there is a clefting construction. 
(17) a. Baineann [m' $]_{\mathrm{FOC}}$ athair-se an t'arbhar le speal reaps my father-FOC1sG the grain with scythe 'MY father reaps grain with a scythe'

b. Beaneann [sei $]_{\mathrm{FOC}}$-sean an t'arbhar le speal reaps he-FOC3SG the grain with scythe 'HE reaps the grain with a scythe'

\subsection{Phonology}

The prosodic structure can express information structure through phrasing, in the pitch accent distribution, or by specific pitch accents or boundary tones. Typically, the effect is to make the focus constituent phonetically prominent. For instance, downstep, a pitch range reduction which naturally goes together with non-prominent meanings, is suspended in a Japanese focused constituent, as a result of its occurrence at the beginning of a downstep domain. As we have seen, corrective focus in Basque is subject to the same constraint. Similarly, if the language has two pitch accents, one for broad focus and one for narrow informational or for corrective focus, the latter can be expected to be more prominent. And of course, a syllable with a pitch accent will be more prominent than one without.

Kanerva (1989) showed that in Chichewa, the right edge of the focus constituent coincides with the boundary of a phrase, identified as the phonological phrase by Truckenbrodt (1995). Phrasing constraints imply that no focus distinctions are possible below the level of the phrasing constituent concerned, as we saw above in the case of Lekeitio Basque. Japanese requires an ip-boundary at the left edge of the focus constituent. Again, since the nature of the prosodic hierarchy ensures that no ip-boundary can appear inside the next lower constituent, the $\alpha$, and $\alpha$-boundaries cannot occur inside the 
morphological domain of the word, constituents of compound words cannot be separately focused (Kubozono 1993);(Gussenhoven 2004, p.205).

There is an extensive literature on the relation between pitch accentuation and information structure in West Germanic (cf. Ladd 1996, p.160). Distributions of pitch accents commonly signal the location of informational and corrective focus in West Germanic languages: deaccented words occur after the focus constituent within the 1 , while before the last pitch accent, accents are obligatory within the focus constituent, but optional before it. Deaccentuation before the focus constituent will be more common when it is corrective (Féry 1993).

Different pitch accents are used in European Portuguese for final and prefinal focus constituents. In (18a), broad-focus (lotes do) café lusitano is given a hat pattern, $\mathrm{H}^{*} \mathrm{H}+\mathrm{L}^{*}$, while the corrective narrow-focus [café] ${ }_{F O C}$ lusitano in (18b) has a double-peaked contour, $\mathrm{H}^{*}+\mathrm{L} \mathrm{H}+\mathrm{L}^{*}$, with the second peak considerably lower than the first (Frota 1998, p. 274).

(18) a.

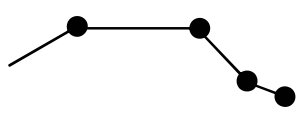

(Aquela loja tambem) vende lotes de café lusitano

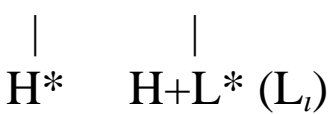

'(That shop also) sells packages of Lusitanian coffee'

b.

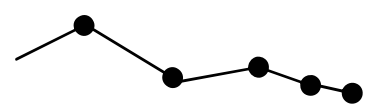

(Tambem vendo) CAFÉ lusitano

'I also sell Lusitanian COFFEE'

Bengali combines all three prosodic means. It requires a phonological phrase $(\varphi)$ boundary after the focus constituent, it deaccents words after the focus 
constituent, and narrow focus is expressed by a different pitch accent than broad (or 'neutral') focus. Example (19a) is a neutral declarative sentence, while $(19 \mathrm{~b}, \mathrm{c})$ illustrate narrow focus contours, with opor $b^{\mathrm{f}} \partial e$ and $k^{h}$ arap as the focus constituents, respectively. Neutral (19a) and narrow-focus (19b) have different pitch accents on the final word. In (19c), the post-focal words [biman-er opor $b^{\mathrm{h}}$ oe] have been deaccented, while an obligatory $\varphi$-boundary occurs after focused [ $\mathrm{k}^{\mathrm{h}}$ arap] where it would not otherwise have occurred.

(19) a.

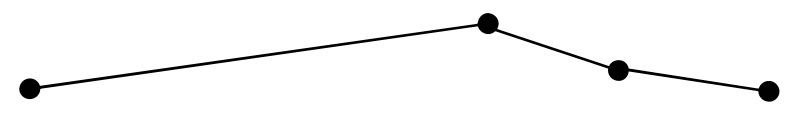

$\left\{\left[\text { amader } \mathrm{k}^{\mathrm{h}} \text { arap biman-er }\right]_{\varphi} \quad\left[\text { opor } \mathrm{b}^{\mathrm{h}} \mathrm{\jmath e}\right]_{\varphi}\right\}_{l}$<smiles>C=[Tl]</smiles><smiles>[121In]</smiles>

our defective aeroplanes-OBJ fear

'Our fear of defective aeroplanes'

b.

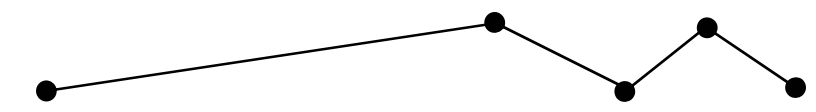

$\left\{\left[\text { amader } \mathrm{k}^{\mathrm{h}} \text { arap biman-er }\right]_{\varphi} \quad\left[\text { opor } \mathrm{b}^{\mathrm{h}} \mathrm{ee}\right]_{\varphi}\right\}_{l}$

|

$\mathrm{L}^{*}$

$\mathrm{H}_{\varphi} \quad \mathrm{L}^{*}$

$\mathrm{H}_{\varphi} \mathrm{L}_{l}$

'Our FEAR of defective aeroplanes'

c.

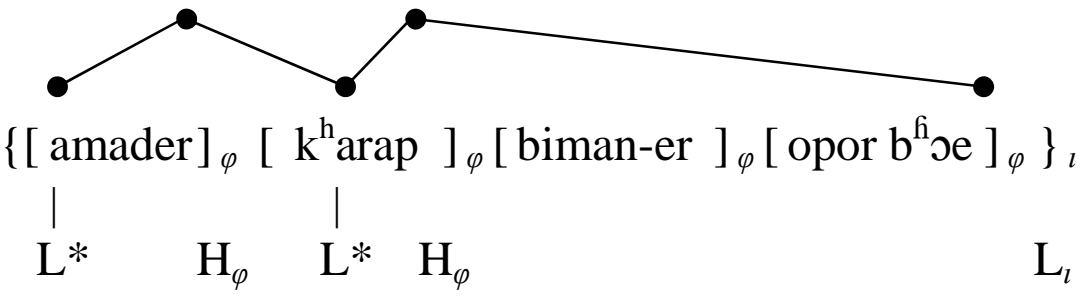

'Our fear of DEFECTIVE aeroplanes'

\subsection{Further focus meanings}

In sections 3 and 3.1, a number of focus types have passed in review: counterpresuppositional focus, corrective focus and information focus. In 
addition, there were two particles expressing 'reactivated' information (Japanese $w a$ and Sundanese tae) and a particle in Sundanese signalling 'given information'. For English, a difference in accentuation was observed according to whether information was prevented from being entered into the mutual knowledge base or whether it was removed from the mutual knowledge base. I conclude the chapter with a meaning distinction based on whether the proposition expresses a definition or a historical event. Russell (1905) was concerned with the question how a proposition including an NP like the King of France, as in The King of France is bald, can have meaning if the NP has no referent. The distinction between 'eventive' and 'non-eventive' is relevant to his discussion to the extent that the quoted sentence, by leaving the prosodic structure unspecified, represents a number of different sentences. Specifically, it is to be noted that, in general, if the update concerns a historical event, whether imagined, completed, future, or otherwise, a different accentuation is used from situations in which the update concerns a further definition of the background. Thus, (20a) is the 'eventive' counterpart of the 'non-eventive' sentence in (20b). (20a) implies that there is a King of France, while (20b) leaves this issue open (Gussenhoven 1984, p. 85). In eventive sentences, new predicates are unaccented (cf. Schmerling 1974; SAAR in Gussenhoven 1983; Gussenhoven 2006), a function of deaccenting in West Germanic that comes on top of the compound rule and deaccenting to mark given information.

(20) a. The KING of FRANCE is bald!

('Something must be done to make his hair grow back')

b. The KING of FRANCE is BALD

('Should there be such a person, his baldness is a matter of course') 


\section{Conclusion}

Instead of emphasizing the commonality in the way languages express information structure, this contribution has focused on the diversity in the meanings and structural encodings of information structure. The grammarspecific nature of the expression of focus could be illustrated with cases of focus ambiguity. Understandably, these will differ across languages as a function of the way focus is encoded. One source of ambiguity was shown to lay in the multiple functions that a focus device may have in a given grammar, such as when deaccenting is used for the formation of compounds as well as for signalling given information status in English. Another source lay in the minimal size of the structural device used to encode focus, such as when pitch accents cannot contrastively associate with subsyllabic constituents, as in English.

\section{References}

Bolinger, D. (1983). Affirmation and default. Folia Linguistica 17, 505-533.

Cotter, C. (1996). Systems in contact: Focus in Irish and English. In A. Henry (ed.), Belfast Working Papers in Language and Linguistics 12, University of Ulster, pp. 85-116.

Dik, S. C., M. E. Hoffmann, J. R. de Jong, S. I. Djlang, H. Stroomer and L. de Vries (1981). On the typology of focus phenomena. In T. Hoekstra, H. van der Hulst \& M. Moortgat, Perspectives on Functional Grammar, Dordrecht:Foris, 41-74.

Elordieta, G. (2007a). Constraints on intonational prominence of focalized constituents. In D. Büring, M. Gordon and C. L. Lee (eds.), Topic and Focus: Papers from a Workshop on Intonation and Meaning, Dordrecht: Kluwer, pp. 1-22.

Elordieta, G. (2007b). A constraint-based analysis of the intonational realization offocus in Northern Bizkaian Basque, pp. 00. 
Elordieta, G. and J. I. Hualde (2003). Tonal and durational correlates of accent in contexts of downstep in Lekeitio Basque. Journal of the International Phonetic Association 33, 195-209.

Féry, C. (1993). German Intonational Patterns. Tübingen: Niemeyer.

Frota, S. (1998). Prosody and focus in European Portuguese. Ph. D. thesis, University of Lisbon. Published by Garland, New York, 2000.

Gussenhoven, C. (1983). Focus, mode and the nucleus. Journal of Linguistics 19, 377-417. Reprinted in Gussenhoven (1984).

Gussenhoven, C. (1984). On the grammar and semantics of sentence accents. Dordrecht: Foris.

Gussenhoven, C. (2004). The Phonology of Tone and Intonation. Cambridge: Cambridge University Press.

Gussenhoven, C. (2007). Types of focus in English. In D. Büring, M. Gordon and C. L. Lee (eds.), Topic and Focus: Papers from a Workshop on Intonation and Meaning, Dordrecht: Kluwer, pp. 83-101.

Gussenhoven, C. and R. Teeuw (2007). A moraic and a syllabic h-tone in Yucatec Maya. pp. 00-00.

Kanerva, J. M. (1989). Focus and Phrasing in Chicheŵwa Phonology. Ph. D. thesis, Stanford University, Palo Alto.

É. Kiss, K. (1998). Identificational focus and information focus. Language 74, 245-273.

Kubozono, H. (1993). The Organization of Japanese Prosody. Tokyo: Kurosio.

Kügler, F. and S. Skopeteas (2006). Interaction of lexical tone and information structure in Yucatec Maya. In A. Belotel-Grenié and M. Grenié (eds.), Proceedings of the Second International Symposium on Tonal Aspects of Languages (TAL-2). Université de La Rochelle, pp. 380-388.

Ladd, D. R. (1980). The Structure of Intonational Meaning: Evidence from English. Bloomington: Indiana University Press.

Ladd, D. R. (1996). Intonational Phonology. Cambridge: Cambridge University Press. 
Müller-Gotama, F. (1996). Topic and focus in Sundanese. Anthropological Linguistics 38, 117-132.

Pierrehumbert, J. B. and M. E. Beckman (1988). Japanese Tone Structure. Cambridge MA: MIT Press.

Rialland, A. and S. Robert (2001). The intonational system of Wolof. Linguistics 39, 893-939.

Robert, S. (1991). Une approche énonciative du système verbal: le cas de wolof. Paris: CNRS.

Robert, S. (2000). Le verbe wolof ou la grammaticalisation du focus. In B. Caron (ed.), Topicalisation et focalisation dans les langues africaines, Louvain/Paris: Peeters, pp. 229-267.

Rudin, C., T. H. King and R. Izvorski (1998). Focus in Bulgarian and Russian yes-no questions. In E. Benedicto, M. Romero, and S. Tomioka (eds.), University of Massachusetts Occasional Papers in Linguistics, Volume 21, pp. 209-226.

Russell, B. (1905). On denoting. Mind 14, 479-493. New Series.

Schmerling, S. F. (1974). Aspects of English Sentence Stress. Austin: Texas University Press.

Sugahara, M. (2002). Conditions on post-FOCUS dephrasing in Tokyo Japanese. Speech Prosody 2002: Proceedings of the First International Speech Prosody Conference, Aix-en-Provence: Laboratoire Parole et Langage, CNRS and Université de Provence, pp. 655-658.

Susumu, K. (1973). The Structure of Japanese Language. Cambridge MA: MIT Press.

Truckenbrodt, H. (1995). Phonological Phrases: Their Relation to Syntax, Prominence and Focus. Ph. D. thesis, MIT.

van Heuven, V. J. (1994). What is the smallest prosodic domain? In P. A. Keating (ed.), Phonological Structure and Phonetic Form: Papers in Laboratory Phonology III, Cambridge: Cambridge University Press, pp. 76-98. 
Carlos Gussenhoven

Radboud University Nijmegen

Department of Linguistics

PO Box 9103

NL-6500 HD Nijmegen

The Netherlands

C.Gussenhoven@let.ru.nl

http://www.ru.nl/taalwetenschap/medewerkerspagina's/c_gussenhoven/ 
